\title{
Fluctuations in the spawning stock biomass and recruitment of the brazilian sardine (Sardinella brasiliensis) 1977-1997
}

\author{
Maria Cristina Cergole'; Suzana Anita Saccardo ${ }^{2} \&$ Carmen L. D. B. Rossi-Wongtschowski ${ }^{3}$ \\ ${ }^{1}$ Instituto Oceanográfico da Universidade de São Paulo \\ (CNPq/Programa REVIZEE) \\ (Praça do Oceanográfico, 191, Butantã 05508-900, São Paulo, SP, Brazil) \\ ccergole@iconet.com.br \\ ${ }^{2}$ Brazilian Institute of Environment and Natural Renewable Resources - Instituto Brasileiro do Meio Ambiente e dos \\ Recursos Naturais Renováveis (IBAMA/São Paulo) \\ (Alameda Tietê, 637, 01417-020, São Paulo, SP, Brazil) \\ suzana@sp.ibama.gov.br \\ ${ }^{3}$ Instituto Oceanográfico da Universidade de São Paulo \\ (Praça do Oceanográfico, 191, Butantã 05508-900, São Paulo, SP, Brasil) \\ cwongski@usp.br
}

- Abstract: In the southeastern coast of Brazil, catches of the Brazilian sardine (Sardinella brasiliensis) have been decreasing from more than 200 thousand tons/year in the early '70s to about 32 thousand tons in 1990 . From 1994 to 1997 , catches recovered slightly (118 thousand tons), dropping then to about 20 thousand tons in 1999-2000. Extensive investigations on biology and stock assessment of Brazilian sardine have been developed in the ' 80 s, providing stock biomass and recruitment estimates based on commercial fishing data obtained from 1977-1992. The present paper aims to update biological and stock assessment parameters from sardine data obtained during two acoustic surveys carried out in 1995 and commercial catches from the 1993-1997 period. Results from both cruises showed the weight-length relationship $\mathrm{Wt}=0.0000019 . \mathrm{Lt}^{3.26}(90-240 \mathrm{~mm}$ total length) and four age classes (mostly class II+). In the commercial catches, sardines belonged to ages $0+$ and $3+$ years old (mostly older than 1 year old) with $90-250 \mathrm{~mm}$ total length. Annual growth parameters were: $\mathrm{L} \infty=275 \mathrm{~mm}, \mathrm{~K}=0.55$ (1996), and $\mathrm{L} \infty=273 \mathrm{~mm}, \mathrm{~K}=0.50$ (1997). Total mortality $(\mathrm{Z})$ and natural mortality $(\mathrm{M})$ coefficients were: $Z=3.8 ; \mathrm{M}=0.7-$ 1.2 (1996), and $Z=3.6 ; M=0.6-1.1$ (1997). The variation amplitude of $M$ is due to the application of several different methods. Considering the historical series of 21 years of data (1977-1997), results showed that the stock went through two favorable periods (1980-84, 1989-94) and one unfavorable period (1985-89). 1997 seems to have been the beginning of a new unfavorable period, revealing recruitment cycles likewise other stocks from California and Japan.

- Resumo: Na costa sudeste do Brasil, as capturas da sardinha-verdadeira (Sardinella brasliensis) decresceram de mais de 200 mil t/ano no início dos anos 70 para cerca de 32 mil t em 1990. De 1994 a 1997, as capturas se recuperaram alcançando $118 \mathrm{mil} \mathrm{t}$, caindo então para cerca de $20 \mathrm{mil} \mathrm{t} \mathrm{em}$ 1999-2000. Estudos abrangentes sobre a biologia e avaliação do estoque da espécie foram desenvolvidos nos anos 80 , permitindo a estimativa da biomassa e recrutamento do estoque com base em dados da pesca comercial durante 1977-1992. Os objetivos do presente trabalho foram atualizar as estimativas dos parânetros biológicos e avaliação do estoque através de dados obtidos durante dois cruzeiros de prospeç̧ão acústica realizados em 1995 e de dados da captura comercial no período 1993-1997. Como resultados de ambos os cruzeiros, a relação peso/comprimento estimada foi: $\mathrm{Wt}=0,0000019 . \mathrm{Lt}^{3,26}$ (amplitude de comprimento total de $90-250 \mathrm{~mm}$ ) e quatro classes etárias (maior freqüência para a classe $\mathrm{II}^{+}$) estiveram presentes. Nas capturas da pesca comercial ocorreram indivíduos de idades $0^{+}$a $\mathrm{III}^{+}$ anos, principalmente adultos com mais de 1 ano de idade e comprimentos entre 90-250mm. Os valores dos parâmetros de crescimento estimados foram $\mathrm{L} \infty=275 \mathrm{~mm}$ e $\mathrm{K}=0,55$ (1996), e $\mathrm{L} \infty=273 \mathrm{~mm}$ e $\mathrm{K}=0,50$ (1997). As taxas de mortalidade total $(Z$ ) e natural $(M)$ foram: $Z=3,8$ e $M=0,7-1,2$ (1996), e $Z=3,6$ e $M=0,6-1,1$ (1997). A amplitude de variação de $M$ se deve ao fato da aplicação de vários métodos diferentes. Considerando-se uma série histórica de 21 anos (1977-1997), os estudos mostraram que o estoque passou por dois períodos favoráveis (1980-84, 1989-94) e um desfavorável (1985-89). O ano de 1997 parece ser o início de um novo período desfavorável, revelando ciclos de recrutamento a exemplo de outros estoques da Califórnia e do Japão.

- Descriptors: Brazilian sardine, Sardinella brasiliensis, Stock assessment, Southeastern Brazilian coast, Recruitment cycles.

- Descritores: Sardinha, Sardinella brasiliensis, Avaliação de estoque, Sudeste, Brasil, Ciclos de recrutamento. 


\section{Introduction}

Among the small economically important pelagic species in Brazil, the Brazilian sardine, Sardinella brasiliensis is the one that suffers the strongest fishing efforts by the commercial fleets. Commercial catches of the sardine began in the late ' 50 s, and had a quick growth in the 60 s, reaching a peak of 228 thousand tons in 1973. During following fourteen years, catches ranged from $90-140$ thousand tons, however, after 1987 there was a significant drop and in 1990 the production was only 32 thousand tons, which really unbalanced all the fishing sector involved.

The collapse of fishery was due to a failure in recruitment caused by a very small spawning stock, not to mention adverse environmental factors at breeding season. It is also important to highlight the major influence of great fishing efforts on the stock due to the action of an overwhelming fishing fleet (IBAMA, 1991, 1992, Valentini \& Cardoso, 1991; Cergole, 1993, 1995).

As from this fact, sardine fishing regulations have been changed and a longer period of prohibition was adopted aiming at protecting not only the spawning period, but also recruitment (IBAMA 1991, 1992). Besides that, fishing fleet was naturally reduced due to fishing conditions and nowadays, nearly $50 \%$ of the fleet is active on this resource as against those in the ' $80 \mathrm{~s}$.

Based on the results of survey cruise in the summer of 1993, Matsuura $(1996,1998)$ reported a recovery in sardine spawning intensity and, in 19961997, catches began to grow again reaching 100 thousand and 118 thousand tons respectively. However, these figures dropped to 82 thousand tons in 1998, and they reached a alarming level in 1999 and 2000, which was lower than that in 1990.

Many biological and fishing studies about the Brazilian sardine have been carried out since 1950, which makes the sardine the most studied species in Brazil. Matsuura (1977) studied its population structure, behavior and early life stages, and Vazzoler (1980) studied its juvenile and adulthood; Saccardo \& Rossi-Wongtschowski (1991) presented a review on population biology and stock assessment; Rossi-Wongtschowski et al. (1995) updated the information and presented a synthesis of the data raised about resource status; and Cergole (1995) assessed the stock considering the data of commercial catches for 1977 1992 by means of a Virtual Population Analysis.

More recent studies have been carried out by Matsuura $(1996,1998)$ who analyzed the sardine spawning between 1979 and 1993; RossiWongtschowski et al. (1996) brought to light the possible causes of catch variations; Sunyé \& Servain (1998) and Sunyé (1999) studied the effects of seasonal oceanographic and meteorological variations on fisheries, and Kurtz (1999) studied survival and growth in larval stages and its effects on recruitment. Vasconcellos (2000), by making use of fishing and ecological data described changes in the sardine recruitment and catch, as well as in the Brazilian southeastern ecosystem structure with objective to find hypotheses about the ecosystem and population resilience when pressured by fisheries. Based on applications of mono and multispecific models, he discussed the risks of possible decisions in the sardine fishery management.

The awareness of stock status for 1993 1997 required an updated sardine age-length key and population parameters. Thus, in the present study, growth and mortality parameters in this period were estimated; age compositions of catches were analyzed and the biomass of this important resource was, therefore, estimated.

\section{Material and methods}

Otoliths of $S$. brasiliensis were obtained from sardine samples caught by middle-water trawl from the acoustic prospecting cruises in the southeastern coast of Brazil related to projects ECOSAR II (winter) and III (spring), carried out in 1995, with R/V "Atlântico Sul" (Fundação Universidade do Rio Grande, FURG). The analysis of the population structures was made following to the methods described in Saccardo et al. (1988) and the sardine's recent age-length key was built.

Data on monthly landing and frequency distributions of length in controlled catches were obtained by IBAMA and by Instituto de Pesca (Secretaria da Agricultura e Abastecimento do Estado de São Paulo). The number of fishes per length class and of controlled catch samples was estimated at total landings based on the weight/length relationship obtained from data collected during the prospecting fisheries of ECOSAR II.

The 1995 age-length key was used to change the length structure into age structure of the catches landed from 1993-1997.

Growth parameter estimates for 1996 and 1997 were made with length data according to the methods described in Cergole \& Valentini (1994). The computer package FISAT (Gayanilo et al., 1996 and Gayanilo \& Pauly, 1997) was used to analyze the distributions of length frequency by means of the routine ELEFAN I (Pauly \& David, 1981), which is based on growth equation with seasonal oscillations proposed by Pauly \& Gaschutz (1979).

The total mortality coefficient (Z) was determined by converted length catch curves, by FISAT, as done by Cergole $(1993,1995)$. The natural 
mortality coefficient (M) was obtained by empirical formulae developed by different authors (Pauly, 1980; Rikhter \& Efanov, 1976; Alverson \& Carney, 1975 and Gunderson \& Dygert, 1988). Fishing mortality coefficient (F) was estimated by the differences between $Z$ and $M$, and the exploitation rate $(\mathrm{E})$ by ratio $\mathrm{F} / \mathrm{Z}$.

The number of sardines in the sea between 1993 and 1997 was determined according to the method applied to determine stocks for 1977 1992 (Cergole, 1995), using the Virtual Population Analysis, through ANACO Program (Mesnil, 1988). The analysis was held on a semester basis, by initially applying a terminal $F$ equal to the value of natural mortality coefficient and. thereafter, equal to the average values of the dominant age classes which were obtained in the first analysis.

Biomass in each age class of each cohort was obtained by multiplying the number of fishes by the individual average weight of the corresponding class and the total biomass $(\mathrm{B})$ in each year, by the sum of the biomass for all age classes.

The annual Spawning Stock Biomass (SSB) was determined according to the maturity ogive (Cergole, 1993), considering 50\% of the biomass to be one year old, $75 \%$ of 1.5 year old and $100 \%$ of other ages.

Concerning recruitment ( $R$ ) for each year, the number of sardines corresponding to the first age group ( 0.5 year old) of each cohort was considered.

\section{Results}

\section{Catch yield}

The values referring to annual sardine (Sardinella brasiliensis) landings for each state and for entire area are shown in Table 1 and Figure 1.

Taking into consideration the total area of sardine distribution, there was an increasing production trend from 1990 1998, in spite of interannual variations. However, catches in 1999 and 2000 suffered a drastic fall and could not achieve 30 thousand tons.

The comparative total catch data analysis in the area comprehending the southeastern region shows that, in the 70`s, the state of Rio de Janeiro (north of sardine distribution area), accounted for the largest number of landings, about $40 \sim 60 \%$. However, in the following decade, production in that state suffered a sharp drop reaching only $10 \%$ of the total amount in 1989. Further on, there was an increasing trend, with values around 19 thousand tons (1995), 35 thousand tons (1996) and 31 thousand tons (1997), corresponding to 33,36 and $26 \%$ of total catches in the southeast. The increase in total catche contribution of Rio de Janeiro state in the period from $1995 \sim 1997$ is an interesting fact, although production returned to very low levels in 1998, nearly 8 thousand tons ( $10 \%$ of the total volume).

In the $80^{\prime}$ s, São Paulo state (central area of sardine occurrence), had an outstanding participation in total production, becoming, however, less meaningful in the $90^{\prime} \mathrm{s}$.

Santa Catarina, south of sardine distribution area, surpassed the other states in the $90^{\circ} \mathrm{s}$, accounting for the largest amount of sardine production in southeastern Brazil.

Then, roughly speaking, sardine catches along the southeastern coast suffered a displacement to the south after the $80^{\circ} \mathrm{s}$, whereas most catches occurred in the northern area in the $60^{\circ} \mathrm{s}$ and $70^{\prime} \mathrm{s}$.

\section{Growth and mortality}

The age-length key for 1995 (Table 2), built from the readings of 165 pairs of otholiths presented 4 age classes, with predominance of class II+ years old. Comparing the age structure of catches from 1993 1997 (Table 3) with those from 1977 1992 (Cergole, 1993), no changes could be noticed. In both periods, the bulk of catches were composed of sardines aging $0+\sim 11+$ years with length between 90 and $250 \sim 270 \mathrm{~mm}$.

Table 4 shows the growth parameters related to the seasonal growth equation obtained for 1996 and 1997. The values found for $L \infty$ and $\mathrm{K}$ in each year are similar and the results of amplitude of seasonal oscillation $(\mathrm{C}=6)$ and of winter point or period of the year when growth is slower $(W p=0.8)$ are the same. The amplitude of seasonal oscillation represents the difference in temperature between summer and winter, which is nearly $6^{\circ} \mathrm{C}$, being compatible with what is observed in the southeastern coast (Castro \& Miranda, 1998). The time of the year when growth was slower corresponds to spring.

Results related to total mortality (Z), natural mortality (M) and fishing mortality (F), as well as exploitation rate $(\mathrm{E})$ coefficients are shown in Table 5. The values of natural mortality in that table correspond to those obtained by applying several empirical formulae, with values varying from 0.6 to 1.2 per year. Aditionally, the $M$ value obtained by Rikhter \& Efanov's formula (1976) was $0.96 /$ year, considering the age of first maturation to be 1.5 years (which corresponds to the length of sardine's first sexual maturity $\mathrm{Lt}=$ $170 \mathrm{~mm}$ )

Figures 2 and 3 show growth curves and Figures 4 and 5 show the converted length catch curves for estimation of total mortality (Z) for years 1996 and 1997. 
Table 1. Annual landings (thousand tons) of Brazilian sardine, Sardinella brasiliensis, per southeastern state in Brazil.

\begin{tabular}{|c|c|c|c|c|c|c|c|c|c|c|c|c|c|c|c|c|c|c|}
\hline \multirow[t]{2}{*}{ STATE } & \multicolumn{18}{|c|}{ YEÄR } \\
\hline & 1964 & 1965 & 1966 & 1967 & 1968 & 1969 & 1970 & 1971 & 1972 & 1973 & 1974 & 1975 & 1976 & 1977 & 1978 & 1979 & 1980 & 1981 \\
\hline R.J & 20.087 & 19.355 & 19.368 & 25.111 & 30.611 & 64.462 & 76.434 & 99.434 & 108.272 & 118.944 & 71.916 & 62.674 & 62.396 & 71.441 & 54.262 & 39.664 & 41.481 & 28.664 \\
\hline SP & 9.054 & 17.426 & 28.194 & 42.751 & 33.848 & 35.342 & 37.04 & 28.245 & 24.168 & 16.661 & 9.61 & 18.21 & 15.846 & 24.733 & 34,397 & 57.662 & 27.824 & 55.797 \\
\hline $\mathbf{P R}$ & 0.256 & 0.193 & 0.212 & 0.285 & 0.294 & 0.402 & 0.375 & 0.322 & 0.118 & 0.044 & 0.342 & 0.63 & 0.104 & 0.017 & 0.026 & 0.043 & 0.066 & 0.054 \\
\hline$S C$ & 9.375 & 13.803 & 11779 & 12.266 & 10.868 & 13.562 & 21561 & 33.026 & 38.148 & 92.388 & 95.221 & 54.59 & 26.93 & 49.385 & 56.0 & 52.213 & 76.905 & 31.864 \\
\hline TOTAL & 38.772 & 50.777 & 59.553 & 80.413 & 75.621 & 113.768 & 135.41 & 161.027 & 170.706 & 228.037 & 177.089 & 136.104 & 105.276 & 145.576 & 144.685 & 149.582 & 146.276 & 116.379 \\
\hline
\end{tabular}

\begin{tabular}{|c|c|c|c|c|c|c|c|c|c|c|c|c|c|c|c|c|c|c|c|}
\hline \multirow[t]{2}{*}{ STATE } & \multicolumn{19}{|c|}{ YEAR } \\
\hline & 1982 & 1983 & 1984 & 1985 & 1986 & 1987 & 1988 & 1989 & 1990 & 1991 & $\overline{1992}$ & 1993 & 1994 & 1995 & 1996 & $\overline{1997}$ & 1998 & 1999 & 2000 \\
\hline RJ & 24.661 & 24.95 & 23.137 & 23.028 & 11.795 & 14.712 & $17.38^{\circ}$ & 8.072 & 7.68 & 8.869 & 8.828 & 5.252 & 9.805 & 19.047 & 34.915 & 30.57 & 8.376 & 7235 & 3.587 \\
\hline SP & 37.575 & 78.579 & 82.84 & 37.89 & 58.16 & 49.42 & 20.984 & 38.628 & 8.767 & 18.927 & 19.953 & 12.303 & 14707 & 15.159 & 18.294 & 19.904 & 6.751 & 5.556 & 6.855 \\
\hline PR & 0.022 & 0.068 & 0.046 & 0.007 & 0.004 & 0 & 0.014 & 0.002 & 0 & 0.085 & 0 & 0 & 0 & 0 & 0 & 0 & 0 & 0 & 4.0 \\
\hline $\mathrm{SC}$ & 36.615 & 35.78 & 31.183 & 63.036 & 56.221 & 27.109 & $26.76 ?$ & 31.406 & 15.634 & 36.413 & 36.061 & 36.008 & 61.505 & 23.162 & 43.875 & 67.149 & 57.156 & 12.727 & 6.607 \\
\hline TOTAL & $98 \overline{873}$ & 139.377 & 137.206 & 123.961 & 126.18 & 91.241 & 65.14 & 78.108 & 32.081 & 64294 & 64842 & 53.563 & 86.017 & 57.368 & 97.084 & 117.623 & 82.283 & 25.518 & 17.053 \\
\hline
\end{tabular}

RJ - Rio de Janeiro State

SP - São Paulo State

PR - Paraná State

SC - Santa Catarina State

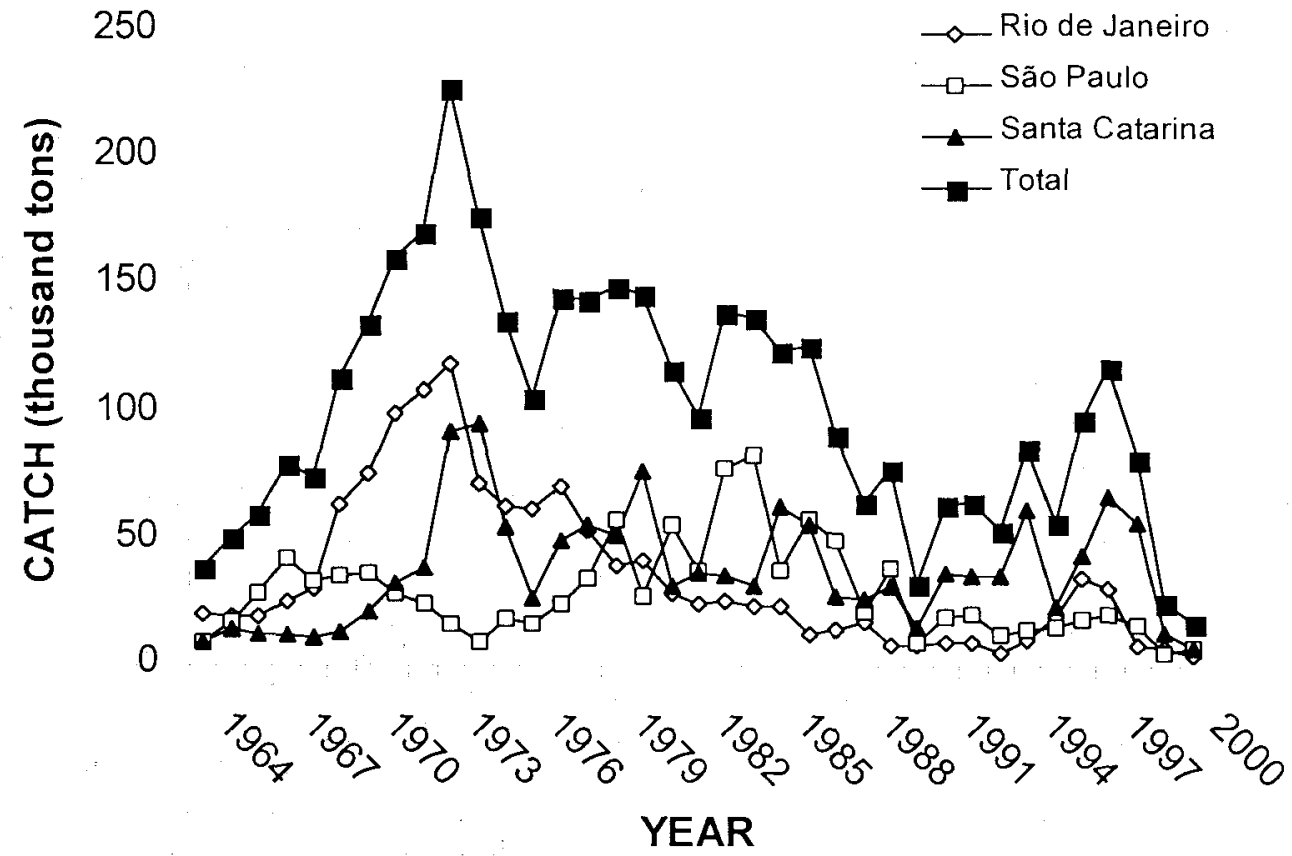

Fig. 1. Total annual landings of Brazilian sardine, Sardinella brasiliensis, for southeastern states of Brazil. 
Table 2. Age-length key for Brazilian sardine, Sardinella brasiliensis, for 1995.

\begin{tabular}{|c|c|c|c|c|c|c|c|c|c|}
\hline \multirow{2}{*}{$\begin{array}{c}\text { AGE } \\
\mathrm{Lt}(\mathrm{mm})\end{array}$} & \multicolumn{2}{|l|}{$0+$} & \multicolumn{2}{|l|}{ It } & \multicolumn{2}{|l|}{ IIt } & \multicolumn{2}{|l|}{$111+$} & \multirow{2}{*}{$\frac{\text { Total }}{\mathrm{N}}$} \\
\hline & $\mathbf{N}$ & $\%$ & $\mathbf{N}$ & $\%$ & $\mathbf{N}$ & $\%$ & $\mathbf{N}$ & $\%$ & \\
\hline 90 & 2 & 66.7 & I & 33.3 & & & & & 3 \\
\hline 100 & 3 & 75.0 & 1 & 25.0 & & & & & 4 \\
\hline 110 & 2 & 33.3 & 2 & 33.3 & 2 & 33.3 & & & 6 \\
\hline 120 & 1 & 11.1 & 6 & 66.7 & 2 & 22.2 & & & 9 \\
\hline 130 & 1 & 14.3 & 4 & 57.1 & 2 & 28.6 & & & 7 \\
\hline 140 & & & 3 & 60.0 & 2 & 40.0 & & & 5 \\
\hline 150 & & & 3 & 50.0 & 3 & 50.0 & & & 6 \\
\hline 160 & & & 2 & 11.1 & 16 & 88.9 & & & 18 \\
\hline 170 & & & 4 & 16.0 & 21 & 84.0 & & & 25 \\
\hline 180 & & & 1 & 4.2 & 23 & 95.8 & & & 24 \\
\hline 190 & & & & & 19 & 95.0 & 1 & 5.0 & 20 \\
\hline 200 & & & & & 11 & 91.7 & 1 & 8.3 & 12 \\
\hline 210 & & & & & 9 & 64.3 & 5 & 35.7 & 14 \\
\hline 220 & & & & & 7 & 70.0 & 3 & 30.0 & 10 \\
\hline 230 & & & & & & & 1 & 100.0 & I \\
\hline 240 & & & & & & & 1 & 100.0 & 1 \\
\hline 250 & & & & & & & & & \\
\hline Total & 9 & & 27 & & 117 & & 12 & & 165 \\
\hline
\end{tabular}

Table 3. Age composition of catches in numbers $(\mathrm{x} 1,000)$ and percentage of Brazilian sardine, Sardinella brasiliensis, for 1996 and 1997

\begin{tabular}{|c|c|c|c|c|c|c|c|c|c|c|}
\hline \multirow{3}{*}{$\begin{array}{c}\text { AGE } \\
\text { (years) }\end{array}$} & \multicolumn{10}{|c|}{ YEAR } \\
\hline & \multicolumn{2}{|l|}{1993} & \multicolumn{2}{|c|}{1994} & \multicolumn{2}{|c|}{1995} & \multicolumn{2}{|c|}{1996} & \multicolumn{2}{|c|}{1997} \\
\hline & $\mathbf{N}$ & $\%$ & $\mathbf{N}$ & $\%$ & $\mathbf{N}$ & $\%$ & $\overline{\mathbf{N}}$ & $\%$ & $\mathbf{N}$ & $\%$ \\
\hline 0 & 2225 & 0.07 & 3541 & 0.21 & 3172 & 0.31 & 836 & 0.05 & 21 & 0.00 \\
\hline 1 & 240021 & 7.60 & 94978 & 5.70 & 79683 & 7.75 & 94164 & 5.23 & 19794 & 1.13 \\
\hline 2 & 2667036 & 84.46 & 1491320 & 89.56 & 837055 & 81.37 & 1557111 & 86.52 & $1 E+06$ & 79.69 \\
\hline 3 & 248308 & 7.86 & 75260 & 4.52 & 108760 & 10.57 & 147567 & 8.20 & 335819 & 19.17 \\
\hline Total & 3157590 & & 1665099 & & 1028670 & & 1799678 & & 1751370 & \\
\hline
\end{tabular}

Table 4. Seasonal growth parameter equation of Brazilian sardine, Sardinella brasiliensis, for 1996 and 1997.

\begin{tabular}{|c|c|c|c|c|}
\hline YEAR & $\mathbf{L} \infty$ & $\mathbf{K}$ & $\mathbf{C}$ & $\mathbf{W p}$ \\
$\mathbf{m m}$ & per year & & \\
\hline $\mathbf{1 9 9 6}$ & 275 & 0.55 & 0.6 & 0.8 \\
$\mathbf{1 9 9 7}$ & 273 & 0.50 & 0.6 & 0.8 \\
\hline
\end{tabular}

Lo = asymptotic length $(\mathrm{mm})$

$\mathrm{K}=$ growth rate (per year)

$\mathrm{C}=$ seasonal oscillations amplitude

$\mathrm{Wp}=$ winter point

\section{Stock Assessment}

Stock assessment for 1993 1997 was held by making use of various natural mortality coefficients, with values between 0.6 and 1.2 per year, according to the results found through the application of the several methods (Table 5).

In such analyses, the sizes of cohort estimated are dependent of the value of $M$ introduced into the Virtual Population Analysis. The larger the coefficient used, the larger will be the estimate of the sizes of cohorts. If it is larger than the real one, the sizes of the estimated cohorts will be larger than should be. In the same way, the cohort estimated will be sub-estimated in case of using smaller coefficient 


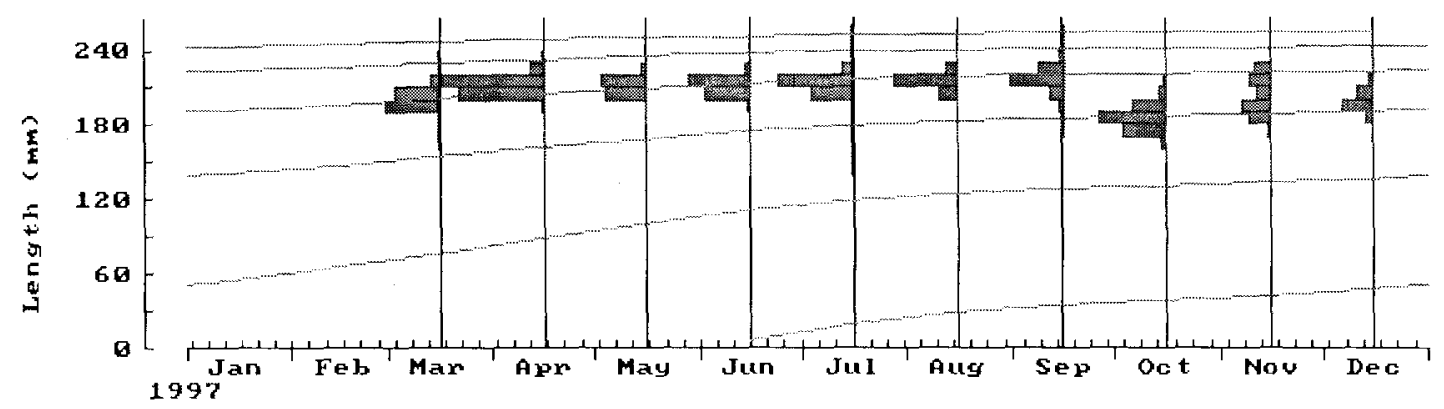

Fig. 2. Sardinella brasiliensis's growth curve for 1996.

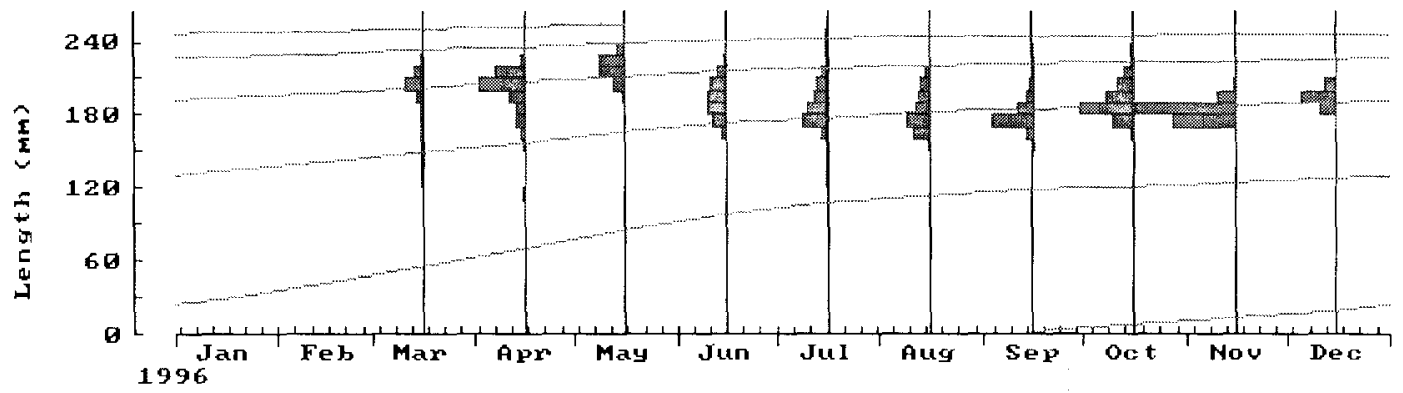

Fig. 3. Sardinella brasiliensis's grow th curve for 1997.

than the true one. Since we are searching tendencies, more than absolute numbers in such analyses, these mistakes can not be serious (Hilborn \& Walters, 1992). Regarding the mortality for fishing estimate in each age (Fi), the larger the coefficient of natural mortality, the smaller Fi, and vice-versa.

Added to the previous data (1977 1992), the results of the Virtual Population Analysis for 1993 1997 complete a historic series of 21 years which can be seen in table 6 , for $M=1.2$ per year. Fishing yield variations and fishing mortality (Fig. 6), recruitment (the number of 0.5 year-old sardines) and spawning stock biomass (Fig. 7) for this period are reported further on.

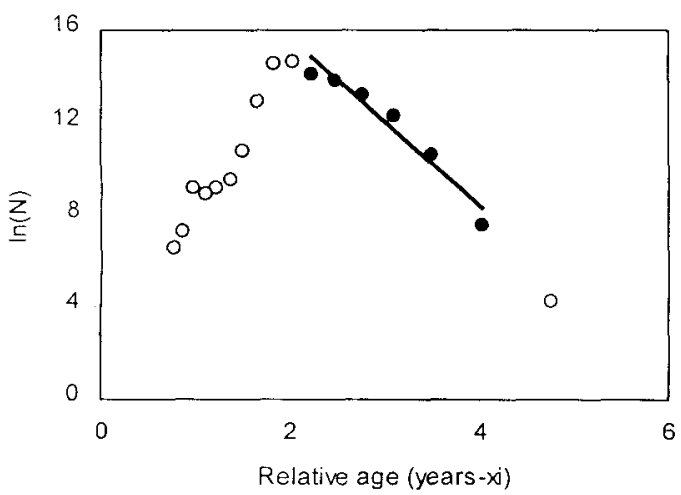

Fig. 4. Catch curve of converted lengths of Sardinella brasiliensis for 1996

$(\bullet$ values used to estimate the total mortality coeflicient

$\left({ }^{\circ}\right)$ not used

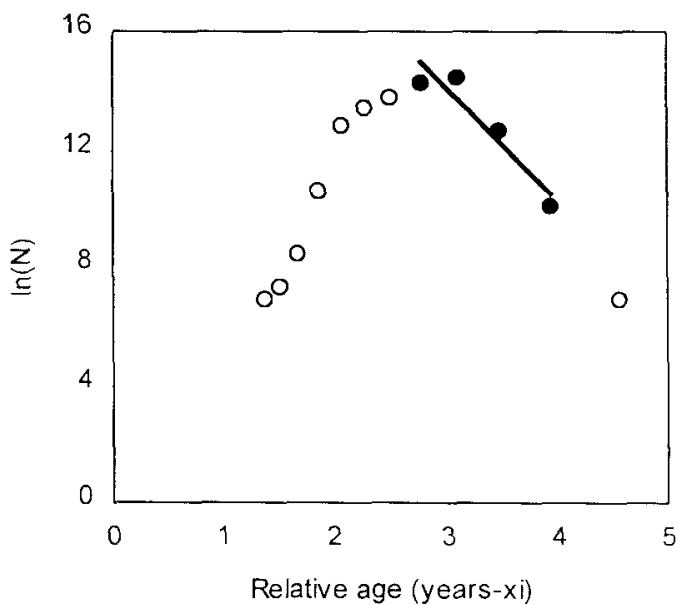

Fig. 5. Catch curve of converted lengths of Sardinella brasiliensis for 1997.

$(\bullet$ values used to estimate the total mortality coefficient

$\left.{ }^{\circ}\right)$ not used

Sardine fishery yield oscillations did not always follow the same trends of fishing mortality variations. As for example, from 1977 1980 yield was constant whereas there was an increase in fishing mortality, and from 1992 1993 yield and fishing mortality had opposite trends (Fig. 6). 
Table 5. Mortality coeflicients and exploitation rates of Brazilian sardine. Sardinella brasiliensis, for 1996 and 1997.

\begin{tabular}{|c|c|c|c|c|c|c|}
\hline \multirow[t]{2}{*}{ IEAR } & \multirow{2}{*}{$\begin{array}{c}7 \\
\text { (catch } \\
\text { curve) }\end{array}$} & \multicolumn{3}{|c|}{ Natural Mortality } & \multirow{2}{*}{$\begin{array}{c}\mathrm{F} \\
(Z-\Lambda 1)\end{array}$} & \multirow{2}{*}{$\begin{array}{c}\mathrm{E} \\
(\mathrm{F} / \mathrm{Z})\end{array}$} \\
\hline & & (a) & (b) & (c) & & \\
\hline 1996 & 3.7 & 0.7 & 0.8 & 1.2 & $2.5-3.0$ & $0.7-0.8$ \\
\hline 1997 & 39 & 0.6 & 0.8 & 1.1 & $2.8-3.3$ & $0.7-0.8$ \\
\hline
\end{tabular}

(a) = Gunderson \& Dygert's (1988) empirical formula

(b) = Alverson \& Camey's (1975) empirical formula

(c) = Pauly's (1980) empirical formula

$\mathrm{I}:=$ Iishing Mortality (per year)

$\mathrm{E}=$ Explotation rate (per year)

Great annual variations were found not only in catches (Fig. 6), but also in spawning stock biomass and recruitment intensity (Fig. 7). Good recruitment levels were noticed in 1991 (30.2 billion fishes) and in 1994 (31.7 billion fishes). Spawning stock biomass remained above the critical level of 180 thousand tons (Cergole, 1995) until 1996, but it fell to 131 thousand tons in 1997. It was also observed that, along all the historic series, a drop in recruitment was followed by a drop in spawning stock with a time gap of one or two years. Analyzing recruitment and spawning stock time variations (Fig. 7), the occurrence of two complete cycles can be found, one in the $80^{\prime} \mathrm{s}$ and another one in the $90^{\prime} \mathrm{s}$, whereas one of them comprehends one ascending period favorable to the stock, and the other one, a descending cycle, not favorable to the stock.

Concerning stock-recruitment relationship (table 6, Figure 8), three stock situations could be found: the first period (1977 to 1986) was characterized by spawning biomass levels between 195 and 407 thousand tons and recruitment between 12.2 and 23.8 billion units; the second period, from 1986 to 1990 , with a spawning biomass ranging from 118 to 219 thousand tons and recruitment from 3.8 to 16.9 billion units; and the last period, (1991 to 1995). showed a spawning biomass between 271 and 419 thousand tons and recruitment between 16.6 and 31.7 billion units.

Jacobson et al. (2001) used the biomass estimations obtained from utilization of $\mathrm{M}=0.96$ per year (Cergole, 1995) for the calculations of | Annual Surplus Production (ASP) and Instantaneous Surplus Production Rate (ISPR) for the Brazilian sardine and for comparison with the other sardine stocks exploited in the Pacific and Atlantic oceans.

In the Virtual Population Analysis, when the coefficient of natural mortality used is $\mathrm{M}=0.96$ per year, the critical biomass for the spawning stock is 150 thousand tons. The biomass of the spawning stock in this case, for year of 1997 is 119 thousand tons, therefore below also of the critical value. The same occurs for other estimatives with different coefficients of $M$.

For the same coefficient of natural mortality, the use of different coefficients for terminal fishing mortalities $(\mathrm{Ft})$ results in different estimates, so much with regard to the fishing mortality in each age class (Fi), as well as the number of individuals in each class (Ni), affecting consequentely the biomass calculation. Errors in $\mathrm{Fi}$ caused by incorrect choice of Ft will be larger in the older age classes, the estimate of $\mathrm{N}$ and $\mathrm{F}$ converge, quickly, in direction to the true value when the fishing mortality is high.

Table 6. Results of the virtual population analysis per year for Brazilian sardine. Sardinella brasiliensis. $\mathrm{M}=1.2$ per year.

\begin{tabular}{|c|c|c|c|c|c|c|c|c|c|c|c|c|c|c|c|c|c|c|c|c|c|c|c|c|}
\hline \multirow[b]{2}{*}{$\begin{array}{c}V P A \\
\text { results }\end{array}$} & \multicolumn{24}{|c|}{ YEAR } \\
\hline & 1977 & 1978 & 1979 & 1980 & 1981 & 1982 & 1983 & 1984 & 1985 & 1986 & 1987 & 1988 & 1989 & 1990 & 1991 & 1992 & 1993 & 1994 & 1995 & 1996 & 1997 & 1998 & 1999 & $2000)$ \\
\hline Y & 146 & 145 & 150 & 146 & 116 & 99 & 139 & 137 & 124 & 126 & 92 & 65 & 78 & 32 & 64 & 65 & 54 & 86 & 57 & 97 & 118 & 82 & 26 & 17 \\
\hline $\mathbf{R}$ & 18.6 & 16.5 & 16.8 & 12.6 & 23.0 & 23.8 & 22.1 & 20.7 & 14.3 & 12.2 & 10.9 & 7.2 & 3.8 & 16.9 & 30.2 & 22.8 & 16.6 & 31.7 & 16.4 & & & & & \\
\hline B & 1240 & 1111 & 916 & 807 & 1001 & 1159 & 1061 & 1098 & 776 & 526 & 400 & 447 & 277 & 829 & 1280 & 1290 & 839 & 1030 & 877 & 419 & & & & \\
\hline SSB & 394 & 394 & 302 & 249 & 195 & 278 & 371 & 407 & 317 & 255 & 177 & 165 & 118 & 210 & 290 & 419 & 344 & 271 & 376 & 333 & 131 & & & \\
\hline mean $\mathrm{F}$ & 0.660 & 0.860 & 1.098 & 1.213 & 1.255 & 0.694 & 0.735 & 0.629 & 0.641 & 1.081 & 1.039 & 0.821 & 1.455 & 0.259 & 0.502 & 0.408 & 0.973 & 0.528 & 0.222 & 0.462 & 2.001 & & & \\
\hline
\end{tabular}

\footnotetext{
$Y=$ Yield (thousand tons)

$\mathrm{R}$ - Recruitment (billion fishes)

$B=$ Total Biomass (thousand tons)

SSB $=$ Spawning Stock Biomass (thousand tons)

mean $F=A$ verage Fishing Mortality
} 


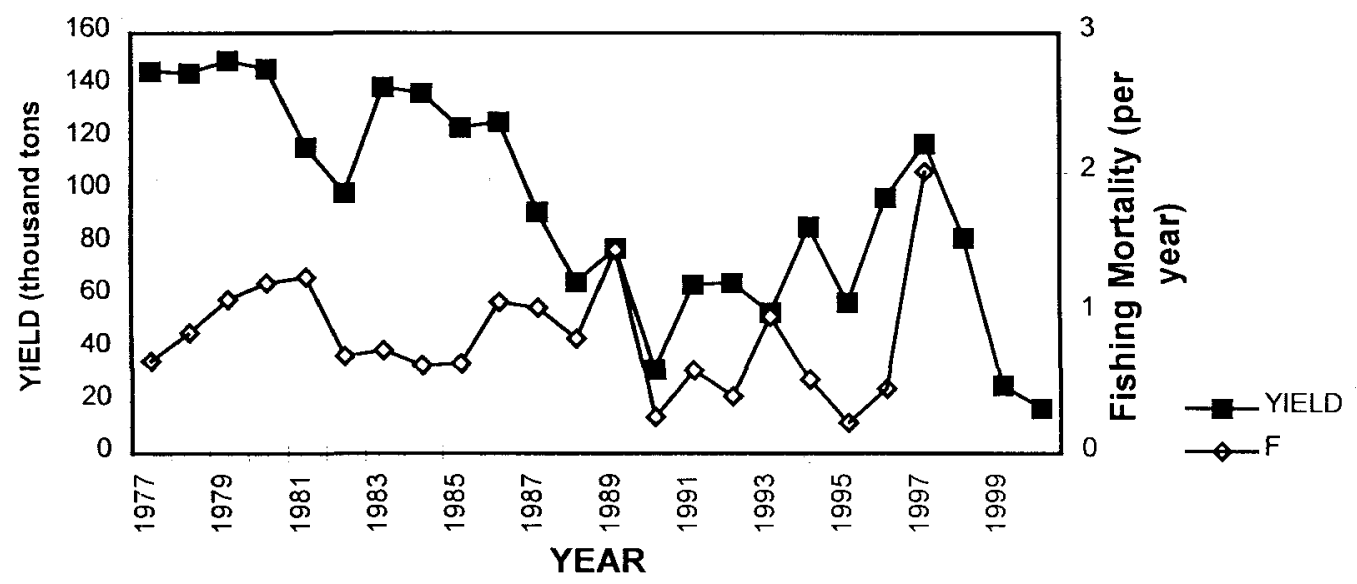

Fig. 6. Annual fishery yield variations and fishing mortality $(\mathrm{F})$ of Sardinella brasiliensis in the southeastern coast of Brazil. $M=1.2$ per year.

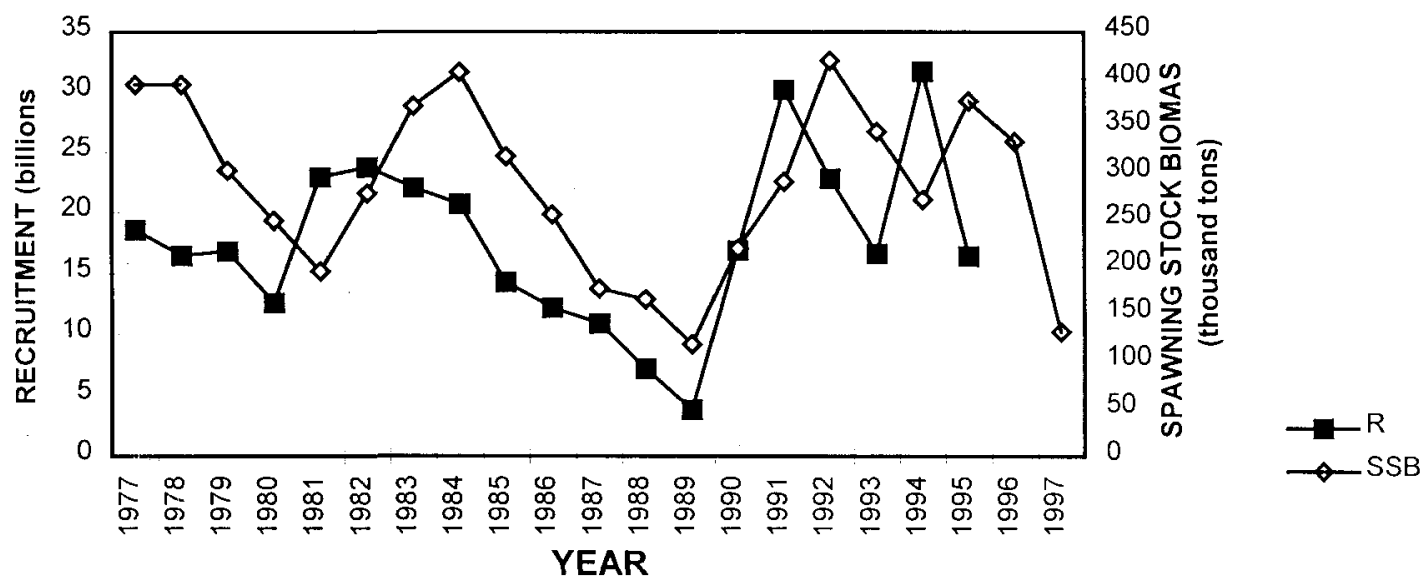

Fig. 7. Annual variatinons of recruitment and spawning stock biomass (SSB) of Sardinella brasiliensis, in the southeastern coast of Brazil. $M=1.2$ per year.

For the same value of $\mathrm{Ft}$, the percentage of error in $\mathrm{Ni}$ and $\mathrm{Fi}$ has the same value and contrary signals, at the same age.

The evaluation of a given stock under exploitation through Virtual Population Analysis in the more recent years is uncertain, once fish of each cohort did not yet pass to vulnerability to fishing in all its life cycle and, therefore, some additional hypotheses are necessary here.

For cohorts 1994, 1995 and 1996 subjected to fishing just partially, the values of $\mathrm{Ft}$ introduced into the analyses were very high, resulting in a striking peak in the average fishing mortality in the last year of the historical series of data (1997), as it can be verified in Figure 6 .
Thus, it was calculated the consequence of a $50 \%$ decrease in the values of $\mathrm{Ft}$ of these cohorts, in the spawning stock biomass estimation and the average fishing mortality of the last year of the historical series of data, considering $M=1.2$ per year. The obtained results indicated that the spawning stock biomass (SSB) showed an increase of the order of $20 \%$, and the 131 thousand tons increased to 165 thousand tons in year of 1997 . It is still below the critical value of 180 thousand tons for the estimate with $\mathrm{M}=1.2$ per year. The average fishing mortality showed a decrease of $40 \%$, going from 2.0 to 1.2 in 1997.

In a simulation of a decrease of $75 \%$ in the values of Ft for cohorts 1994, 1995 and 1996, it was 


\section{$M=1.2$}

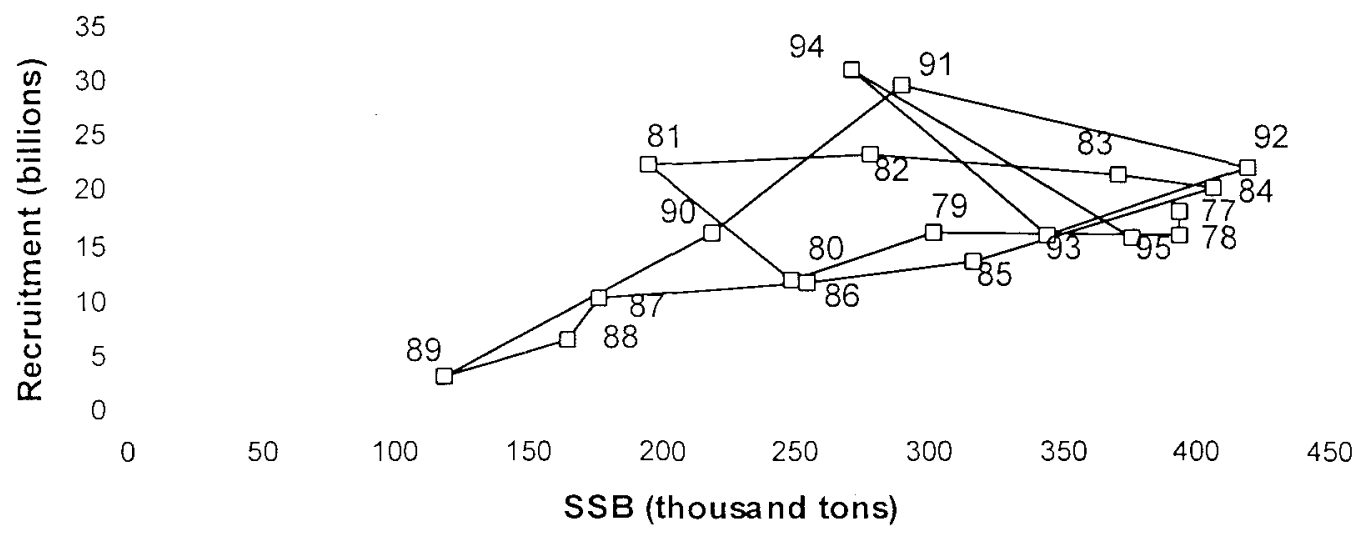

Fig. 8. Stock/recruitment relationship of Sardinella brasiliensis in Southeastern Brazil for the period from 1977 to 1995. $\mathrm{M}=1.2$ per year.

obtained a biomass of 243 thousand tons of adult stock. and an average coefficient of fishing mortality of 0.7 for the year of 1997. In this case. adults' biomass stays above the critical value of 180 thousand tons.

In spite of this last result, it is preferable to consider that the size of the spawning stock was small in 1997, below the critical value, once catches from 1999 on reached levels inferior to that considered as collapse of the fishery in 1990 (32 thousand tons). In the two years that preceded the first collapse, the sizes of the adult stocks also were below the critical being 165 thousand tons in 1988 and 118 thousand tons in 1989

\section{Discussion}

In spite of the quantity and quality of studies available about Brazilian sardine (Sardinella hrasiliensis) stock fluctuations have not been satisfactorily and definitely explained until now.

Long-term variations in marine and freshwater environments are one of the greatest threats for lishery sustainability. Such changes directly affect production. especially recruitment and cause severe confusion in management systems when assessment scientists camnot distinguish between climate and harvesting impacts (Walters \& Parma, 1996).

The awareness of recruitment control mechanisms has been taken as a major factor to understand annual catch fluctuations occurred in most existing fishing resources. mainly the clupeidae. Three factors logether would be responsible for the success of sardine recruitment, called the fundamental triad: the water column enrichment, food concentration, and larvae retention (Bakun, 1996). Therefore, sardine recruitment intensity depends on the development of the early stages of its life cycle occurring within an optimal environmental window (Cury \& Roy, 1989) which could favor this triad.

If recruitment can be understood as a future production rate of stock, then a series of failed recruitments may cause a depletion of the adult stock. High exploitation rates on a depleted stock (depensatory effect - Walters \& Parma, 1996) can turn decline into collapse.

In the Brazilian sardine fishery, evidences of collapse in the late $80^{\circ} \mathrm{s}$ and early $90^{\circ} \mathrm{s}$ made us believe that fishing and environmental factors together resulted in the lowest yield ever noticed in the history of fishery (Cergole, 1993,1995; Rossi \& Wongtschowski et al., 1995). After the collapse, catches began to increase again due to good recruitments for the spawns of 1992 and 1993 (Matsuura, 1998 and Kurtz, 1999), resulting in strong year classes which have helped catches as from 1994. reaching a level higher than 100 thousand tons in 1997. However, catches were nearly $30 \%$ lower in 1998 , and they continued to fall characterizing a new collapse in 1999 and 2000, whereas spawning stock biomass in 1997 was already in a critical situation for the stock

In Vasconcellos's opinion (2000), evidences described in literature, models of simulations applied by him and recruitment-stock data lead to three generic hypotheses to explain Brazilian sardine recruitment variations:1) the overfishing hypothesis considers that fisheries were the major cause for stock 
collapse, and once its intensity is lowered, the stock can return to their original abundance; 2) the hypothesis of environmental change and depensation considers the stock fell in answer to overfishing, but recovery was curbed by recruitment rates decompensation as well as ecosystem changes possibly caused by ecological and behavioral processes; 3) the hypothesis of regime changes considers that stock collapsed in answer to overfishing and recruitment failures caused by low frequency and long-term environmental effects.

Sardine spawning occurs on a yearly basis during the end of spring and summer and the main spawning areas change year by year. The spawning peak coincides with oceanographic processes which allow the South Atlantic Central Waters (SACW) to penetrate the internal continental shelf (Castro et al. 1987; Bakun \& Parrish, 1990; Castro, 1990; Matsuura, 1990; Campos et al., 1995; Matsuura, 1998; Campos et al., 2000).

Matsuura (1998) has assessed sardine spawn on the Brazilian southeastern continental shelf from 1976 1993 and could confirm a displacement of the spawning areas heading south of the distribution area after 1980. Also, in the same period, sardine distribution area became more restricted, being stocks more concentrated in the south (RossiWongtschowski et al., 1995). Likewise, catch variations in the states of Rio de Janeiro, São Paulo and Santa Catarina indicated a displacement of population to the south (table 1, Figure 1).

In Vasconcellos's (2000) view, sardine stock concentration to the south would be the result of better environmental conditions in the area and the low stock biomass would force shoals to occupy a more restrict geographical area ("range collapse").

Rossi-Wongtschowski et al. (1996) presented hypotheses on possible causes of fluctuations in Brazilian sardine population in terms of regional phenomena, aspects related to fishery itself and long-scale climate changes.

In relation to the regional phenomena hypothesis, some authors (Matsuura, 1990, 1996, 1998; Matsuura et al., 1992; Sunyé \& Servain, 1998 and Sunyé, 1999) have attributed stock fluctuations to regional oceanographic variations, mainly to SACW penetration intensity. But, Sunyé (1999) also suggests that the drop in sardine fisheries in the north side and the increase in the south side of its distribution area observed between the $60^{\prime} \mathrm{s}$ and the $90^{\prime} \mathrm{s}$, can be related to decadal climate changes.

Regarding the Brazilian sardine fishery, the purse-seine fleet that operates in the southeast coast, was considered excessive at the end of the 80's and suffered a reduction of about $50 \%$ in boat numbers until year 2000 . This reduction was larger $(75 \%)$ in the center of the sardine distributional area, and lower in the north $(20 \%)$ and south $(30 \%)$. The southern fleet is composed by larger and better equiped boats in comparison to other areas.

Considering that the sardine stock is more concentrated in the southern area, fishery effects on collapse observed in 1999 and 2000 might have been important, in spite of the reduction of the fleet size.

The hypothesis related to the effect of long term climatic changes on sardine and anchovy populations that occur in the coastal systems of Pacific and Atlantic Oceans has been widely argued (Schwartzlose et al., 1999).

For clupeoid stocks, alternating decadal periods of high abundance/catch and low abundance/catch are called regime by Wada \& Jacobson (1998). Decadal-scales regimes of sardine and anchovy populations have been observed in the productive coastal waters of the the Northwestern, Northeastern and Southeastern Pacific and Southeastern Atlantic. Regime changes may be associated to global climate changes which influence marine ecosystems and can be seen in different regions of the world, occurring simultaneously. The existence of simultaneous fluctuations of low frequency of sardine fisheries are well documented for the Pacific Ocean, being preliminarily attributed to inter-relationships among patterns of atmospheric and oceanic circulations (Bakun, 1996; Schwartzlose et al., 1999: Jacobson et al., 2001).

Matsuura (1999) made a review of the most recent findings on the relationships between widescale fluctuations in small pelagic fish populations and decadal scale climate changes.

Wada \& Jacobson (1998) estimated the abundance and stock/recruitment relationship, identifying and characterizing sardine regimes along the coast in Japan from 1951 1995, a period when there was an interval of abundance increase and at least two intervals of low abundance or decrease. The unfavorable regime for the Japanese sardine which started in 1987 continued to reduce abundance and stock recruitment until the end of the period referred to by the authors.

For the Californian sardine, Barnes et al. (1992) and Jacobson \& MacCall (1995) showed that sardine abundance was sensitive to fishery pressures during periods of unfavorable climate conditions. Wada \& Jacobson (1998) believe that the same can be true for the Japanese sardine.

The most important point when managing fisheries of small pelagic fish is to keep high abundance regimes for as long as possible, bearing in mind that fisheries can reduce the extension and duration of high abundance peaks, as well as worsen and prolong low abundance periods. The worst scenario for fishery is to have the need to take precautions for the stock recovering, being forced to catch few fish at high abundance times (Schwartzlose et al., 1999). 
In a previous Brazilian sardine stock assessment, Cergole (1995) had evidenced two situations in the stock-recruitment relationship: one favorable (1977-1986) with good recruitments and spawning stock biomasses; the other one unfavorable (1986-1990) and considered as fishery collapse. The collapse was caused by a combined action of excessive fishing efforts and adverse environmental factors, resulting in restrict spawning stocks and lowintensity annual recruitments.

A third situation (1991-1995) evidenced by analyses made in the present study, indicates another favorable phase with great interannual variations and spawning stocks above critical values. As to recruitment intensity, high values were obtained for 1991 and 1994, nearly 30 32 billion units (these values are higher than those found in the first favorable period), whereas lower values with approximately 16 billion units were found for 1993 and 1995. Although the Virtual Population Analysis was held until 1997, results regarding recruitment intensity could not be estimated for 1996 and 1997 due to limitation of the method applied.

The year of 1997 seems to be the beginning of a new unfavorable period for the stock, in that the fall in spawning stock biomass shows an unstable situation which caused the decrease in production in 1998, and further declines in 1999 and 2000. The current stock situation indicates, therefore, one more period of stock depletion.

The variations observed in spawning stock biomass and in recruitment intensity as from the $70^{\circ} \mathrm{s}$, do not only show intereannual fluctuations, but also a multiannual variation, superimposed to annual variations.

The decline noticed in the late 80 's occurred due to an oceanographic abnormality in the 1986/87 spawning season caused a failure in the 1987 year class recruitment and resulted in a drastic fall in spawning stock biomass in the following years (Castello et al., 1991; Matsuura et al. 1992; Cergole, 1995; Matsuura, 1998). With the drop of these values in the late 90 's, a new cycle of spawning stock biomass and recruitment could be evidenced. Thus, two recruitment cycles can be observed in the last 20 years, one in the 80's and the another in the 90's. After 1989 , the beginning of a new favorable period was evident, and the intensity of the recruitment in 1992 was about 10 times greater than in 1989. However, the following recruitment cycle is marked by striking interannual variations, suggesting a great instability of the stock. Catches remained low since 1999, without recovery signals until the moment. These interannual variations can be reflecting densitydependent effects in the growth and mortality of the stock or environmental effects. Wada and Jacobson (1998) suggest that the density-dependent effects in the recruitment are typical in sardine populations, but difficult to measure in the absence of a long series of data as well as models that accommodate environmental variations. In contrast with densitydependent effects, environmental effects in stocks of small pelagic are frequently more dramatic, even in small time series, because many small pelagic have short life span and are planktivorous.

It is known that strong annual classes leads to a rapid growth in population whereas weak annual classes result in a quick decrease in population. Episodic environmental effects seem to work as a trigger to change spawning intensity, larvae survival and consequently recruitment. This may be the case for the Brazilian sardine, besides the fishery effect, in that a highly efficient fleet is working on stocks located south of its distribution area.

These facts confirm the hypothesis of regime change formulated by Vasconcellos (2000) who attributed the collapse of this stock to overfishing and recruitment failures caused by environmental effects. However, due to fact that the series of available data is still small (approximately 20 years) one cannot mention that this is a "regime". Instead, one may speak of recruitment cycles attributed to overfishing and recruitment failures caused by environmental changes.

Measures of fishery regulations for the Brazilian sardine have been applied since 1976, based on effort control and size limitation on the first-catch. According to Vasconcellos (2000), effort control is particularly unsuitable to avoid stock collapse due to combined effects: a great fleet capacity, catch changes with the size of stock, variations in production rates guided environmental regimes, and biological and behavioral aspects of the species. Besides, if compared the fishery effort applied to the stock in 1990 with that in 1991 , he demonstrated that the effort can be temporarily displaced, but it will be much higher when the fishery is reopened again, to compensate the closure period. It is worth noting that up to 1990 , regulation measures included a closure period in summer to protect spawning stock. In 1991, a new closure period was also established in winter in order to protect sardine recruitment. Vasconcellos (2000) showed that fishing efforts were allocated in spring and fall to offset fishery closure periods in summer (spawning period) and in winter (recruitment).

The best equilibrium between average catches, catch variations and collapse probabilities can be reached by means of catch quota system, such as those obtained from a constant production rate. However, the success of catch quota system depends on the frequency and accuracy of stock abundance estimates. The absence of a systematic research work on sardine population resulted on doubts about the parameters and variables used in biomass and recruitment estimate procedures.

For the Brazilian sardine, the fishingbiological sampling system on commercial landings 
Rev. bras. oceanogr. $50($ único). 2002

has suffered a discontinuation as from the late $80^{\circ} \mathrm{s}$, which has made population parameters and stock size estimates updates a difficult task. The length data of sardine samples in controlled catches obtained during 1993 1997, and the biological samples coming from acoustic surveys held in 1995 provided the necessary material for a new age-length key, making the present study possible. Although we are able to give an idea of spawning stock biomass and recruitment variation trends, we stress the need for annual age-length keys and constant population parameter updates in order to obtain a suitable handling of stocks, besides checks by means of periodical fishery prospecting surveys.

Being so, aiming to introduce fishery order measures based on optimum catch rates, it is necessary to resume the annual monitoring of exploitable stocks through stock assessment surveys, systematic biological sampling to assess the biological parameters, specially spawning and growth. These studies must be followed by the assessment of the characteristics and dynamics of the fleet acting on the sardine stock.

In parallel to the studies of exploitable stocks, studies on the mechanisms responsible for recruitment variation are suggested, based on new focuses as suggested by Kurtz (1999), e. g.: food selectivity, individual larval condition and related physical and biological processes, time follow-up of a cohort from spawn and measure of vital parameters (survival and growth) along the spawning season and area, and predatory effects including cannibalism.

Nowadays, due to short availability of the Brazilian sardine in southeastern coast, the purseseine fleet began to capture intensively other species such as Scomber japonicus, Opisthonema oglimum, Trachurus lathami, Chloroscombrus chrysurus, Selene setapinnis, etc. With this new dynamics, the fleet is now considered as having a multi-specific activities. It is now necessary another approach in fishery management, based on new concept of the fleet as a management unit.

It is previsible, however, that when the first signal of the sardine stock recovery will appear, the fleet will return to catch sardine as a main target species.

Finally we can conclude that it is especially important to have control on minimum size of first catch, to protect first reproduction classes, because of the high natural mortality rate and early maturity of the species.

\section{Acknowledgements}

We are greatly thankful to Instituto de Pesca da Secretaria da Agricultura e Abastecimento do Estado de São Paulo, especially to Dr. Hélio Valentini and to Centro de Pesquisa e Extensão Pesqueira das
Regiões Sudeste e Sul do Instituto Brasileiro do Meio Ambiente e Recursos Naturais Renováveis (CEPSUL/IBAMA) for supplying sardine length data at landings in the states of São Paulo and Santa Catarina respectively.

\section{References}

Alverson, D. L. \& Carney, M. J. 1975. A graphic review of the growth and decay of population cohorts. J. Cons. int. Explor. Mer, 36(2):133143.

Bakun. A. 1996. Patterns in the ocean: ocean processes and marine population dynamics. University of California, California Sea Grant College System. 323p.

Bakun, A. \& Parrish, R. H. 1990. Comparative studies of coastal pelagic fish reproductive habitats: the Brazilian sardine (Sardinella churita). J. Cons. int. Explor. Mer., 46(3):269-283.

Barnes, J. T.; Jacobson, L. D ; MacCall. A. D. \& Wolf, P. 1992. Recent population trends and abundance estimates for sardine (Sardinps sagax). Calif. coop. oceanic Fish. Invest. Rep., 33:60-75.

Campos, E. J. D.; Gonçalves, J. E. \& Ikeda, Y. 1995. Water mass characteristics geostrophic circulation in the south Brazil Bight - summer of 1991. J. geophys. Res., 100(C9):18537-18550.

Campos, E. J. D.; Velhote, D. \& Silveira, I. C. A. 2000. Shelf break upwelling driven by Brasil Current cyclonic meanders. Geophys. Res. I,etts, 27(6):751-754.

Castro, B. M. de 1990. Estado atual do conhecimento dos processos físicos das águas da plataforma continental sudeste do Brasil. In: SIMPÓSIO DE ECOSSISTEMAS DA COSTA SUL E SUDESTE BRASILEIRA: ESTRUTURA, FUNÇÃO E: MANEJO. 1. Águas de Lindóia, 1990. Anais. São Paulo. ACIESP, $1: 1-19$.

Castro, B. M. \& Miranda, L. B. de 1998. Physical oceanography of the western Atlantic continental shelf located between $4^{\circ} \mathrm{N}$ and $34^{\circ} \mathrm{S}$ coastal segment (4,W). In Robinson, A. R. \& Brink, K. H. eds. The Sea. New York, John Wiley \& Sons. 11:206-251.

Castro, B. M. de; Miranda, L. B. de \& Miyao, S. Y 1987. Condições hidrográficas na plataforma continental ao largo de Ubatuba: Variações sazonais em média escala. Bolm Inst. oceanogr., $\mathrm{S}$ Paulo, 35(2):135-151. 
Castello, J. P.; Habiaga, J. C.; Lima Jr., I.D'A. 1991. Prospecção hidroacústica e avaliação da biomassa de sardinha e anchoita, na região sudeste do Brasil (outubro/novembro de 1988). Publções esp. Inst. Oceanogr., S Paulo. (8):1530 .

Cergole, M. C. 1993. Avaliação do estoque da sardinha, Sardinella brasiliensis, da costa sudeste do Brasil, período 1977 a 1990. PhD. Thesis. Universidade de São Paulo, Instituto Oceanográfico. $245 \mathrm{p}$.

Cergole, M. C. 1995. Stock assessment of the Brazilian sardine, Sardinella brasiliensis, of the southeastern Coast of Brazil. Sci. Mar., 59(34):597-610.

Cergole, M. C. \& Valentini, H. 1994. Growth and mortality estimates of Sardinella brasiliensis in the southeastern Brazilian bight. Bolm Inst. oceanogr., S Paulo. 42(1/2):113-127.

Cury, P. \& Roy, C. 1989. Optimal environmental window and pelagic fish recruitment success in upwelling areas. Can. J. Fish. aquat. Sci., $46(4): 670-680$.

Gayanilo Jr. F.C.; Sparre, P.; \& Pauly, D. 1996. FAO-ICLARM stock assessmente tools: User's Guide. FAO, Comput. Inf. Ser. Fish., (8): 1126.

Gayanilo Jr., F. C. \& Pauly, D. 1997. FAOICLARM stock assessment tools: Reference Manual. FAO Comput. Inf. Ser., Fish.. (8): 1-262.

Gunderson, D. R. \& Dygert, P. H. 1988. Reproductive effort as a predictor of natural mortality rate. J. Cons. int. Explor. Mer, 44(2):200-209.

Hilborn, R. \& Walters, C. J. 1992. Quantitative fisheries stock assessment: choice, dynamics $\&$ uncertainty. New York, Chapman and Hall. 570 p.

IBAMA. 1991. Relatório da reunião do grupo permanente de estudos sobre sardinha. Itajaí, IBAMA/CEPSUL. 16p.

IBAMA. 1992. Relatório da reunião técnica sobre sardinha. Itajaí, IBAMA/CEPSUL. $8 p$.

Jacobson, L. D. \& MacCall, A. D. 1995. Stockrecruitment models for Pacific sardine (Sardinops sagax). Can. J. Fish. aquat. Sci, 52(3):566-577.
Jacobson, L. D.; De Oliveira, J. A. A.; Barange, M.; Cisneros-Mata, M. A.; Félix-Uraga, R.; Hunter, J. R.; Kim. J. Y.; Matsuura, Y.; Ñiquen, M.; Porteiro, C.; Rothschild, B.; Sanchez, R. P; Serra, R.: Uriarte, A. \& Wada, T. 2001. Surplus production, varability, and climate change in the great sardine and anchovy fisheries. Can. J. Fish. aquat. Sci., 58(9):1891-1903.

Kurtz, F. W. 1999. Dinâmica larval de Sardinella brasiliensis (Steindachner, 1879) (Teleostei, Clupeidae) na região sudeste do Brasil e implicações no recrutamento. PhD. Thesis. Universidade de São Paulo, Instituto Oceanográfico. $169 \mathrm{p}$.

Matsuura, Y. 1977. O ciclo de vida da sardinhaverdadeira (introdução à oceanografia pesqueira) Publção esp. Inst. oceanogr., S Paulo, (4):1-146.

Matsuura, Y. 1990. Rational utilization of coastal ecosystem in tropics: integrated investigation of coastal ecosystem in Ubatuba region. In: SIMPÓSIO DE ECOSSISTEMAS DA COSTA SUL E SUDESTE BRASILEIRA: ESTRUTURA, FUNÇÃO E MANEJO, 2. Águas de Lindóia. 1990. Anais. São Paulo. AClESP, 1:47-52.

Matsuura, Y. 1996. A probable cause of recruitment failure of the Brazilian sardine Sardinella anrita population during the 1974/75 spawning season. S. Afr. J. mar. Sci., 17:29-35.

Matsuura, Y. 1998. Brazilian sardine (Sardinella brasiliensis) spawning in the southeast Brazilian Bight over the period 1976-1993. Rev. bras. oceanogr.. 46(1):33-43.

Matsuura, Y. 1999. Large-scale fluctuations of small pelagic fish populations and climate changes: a review. Bull. Tohoku Natl. Fish. Res. Inst., (62): 195-205.

Matsuura, Y.; Spach, H. L. \& Katsuragawa, M. 1992. Comparison of spawning patterns of the Brazilian sardine (Sardinella brasiliensis) and anchoita (Engraulis anchoita) in Ubatuba region, southern Brazil during 1985 through 1989. Bolm Inst. oceanogr., S Paulo, 40(1/2):101-115.

Mesnil, B. 1988. Computer programs for fish stock assessment. ANACO: Software for the analysis of catch data by age group on IBM PC and compatibles. FAO Doc. Tech. Pap., 101(sup. 3):173.

Pauly, D. 1980. On the interrelationships between natural mortality, growth parameters, and mean environmental temperature in 175 fish stocks. J. Cons. int. Expl. Mer, 39(2): 175-192. 
Pauly, D. \& David, N. 1981. ELEFAN I, a BASIC program for the objective extraction of growth parameters from length-frequency data. Meeresforsch, 28(4):205-211.

Pauly, D. \& Gaschutz, G. 1979. A simple method for fitting oscillating length growth data, with a program for pocket calculators. ICES C.M. 1979/G, 24:1-26. (mimeo).

Rikhter, V. A. \& Efanov, V. N. 1976. On one of approaches to estimation of natural mortality of fish populations. ICNAF Res. Doc., 76(VI,8): $1-12$.

Rossi-Wongtschowski, C. L. D. B.; Saccardo, S. A. \& Cergole, M. C. 1995. Situação do estoque da sardinha (Sardinella brasiliensis) no litoral sudeste e sul do Brasil. IBAMA/CEPSUL, Coleção Meio Ambiente. Série Estudos Pesca, 17:1-45.

Rossi-Wongtschowski, C. L. D. B.; Saccardo, S. A. \& Cergole, M. C. 1996. Are fluctuations in Brazilian Sardine catches related to global-scale climatic changes? An. Acad. Bras. Ci., 68(supl. 1):239-250.

Saccardo, S. A. \& Rossi-Wongtschowski, C. L. D. B. 1991. Biologia e avaliação do estoque da sardinha Sardinella brasiliensis: uma compilação. Atlântica, Rio Grande, 13(1):29-43.

Saccardo, S. A; Cergole, M. C. \& Bittencourt, M. M. 1988. Age and growth of the southeastern Brazilian sardine, Sardinella brasiliensis, 198183. Bolm Inst. oceanogr., S Paulo, 36(1):17-35.

Schwartzlose, R. A.; Alheit, J.; Bakun, A.; Baumgartner, , T. R.; Cloete, R.; Crawford, R. J. M.; Fletcher, W. J.; Green-Ruiz, Y.; Hagen, E.; Kawasaki, T.; Lluch-Belda, D.; Lluch-Cota, S. E.; MacCall, A. D.; Matsuura, Y.; Nevarez-Martinez, M. O.; Parrish, R.H.; Roy, C.; Serra, R.; Shust, K. V.; Ward, M. N. \& Zuzunaga, J.Z. 1999. Worldwide large-scale fluctuations of sardine and anchovy populations. S. Afr. J. mar. Sci., $21: 289$ 347.

Sunyé, P. S. 1999. Effet de la variabilité climatique régionale sur la pêche de la sadinelle le long de la côte sud-est du Brésil (1964-1993). These de Doctorat. Bregtane, Université de Bretagne Occidentale, Institut Universitaire Européen de la Mer. $130 p$.
Sunyé, P. S. \& Servain, J. 1998. Effects of seasonal variations in meteorology and oceanography on the Brazilian sardine fishery. Fish. Oceanogr., $7(2): 89-100$

Valentini, H. \& Cardoso, R de D. 1991. Análise da pesca da sardinha-verdadeira, Sardinella brasiliensis, na costa sudeste-sul do Brasil. Atlântica, Rio Grande, 13(1):45-54.

Vasconcellos, M. 2000. Ecosystem impacts of fishing forage fishes: an analysis of harvest strategies for the Brazilian sardine. PhD. thesis. Vancouver, University of British Columbia. 190p.

Vazzoler, A. E. de M. 1980. Sardinella brasiliensis (Steindachner, 1879): estudo sobre estrutura e comportamento através de métodos bioquímicos e sobre ciclo de vida das populações na área entre 22 e $28^{\circ} \mathrm{S}$, Brasil, Projeto Megalosar. Relatório submetido à FAPESP.

Wada, T. \& Jacobson, L. D. 1998. Regimes and Stock-Recruitment Relationships in Japanese Sardine (Sardinops melanostictus), 1951-1995. Can. J. Fish. aquat. Sci., 55(11):2455-2463.

Wada, T. \& Kashiwai, M. 1989. Changes in growth and feeding ground of Japanese Sardine with fluctuations in stock abundance. In: Kawasaki, T.; Tanaka, S.; Toba, y. \& Taniguchi, A. Long-term variability of pelagic fish populations and their environment. New York, Pergamon Press. p.181190.

Walters, C. \& Parma, A. M. 1996. Fixed exploitation rate strategies for coping with effects of climate change. Can. J. Fish. aquat. Sci., 53(1):148-158.
(Manuscript received 25 March 2002; revised 17 September 2002; accepted 29 October 2002) 